\title{
Benthic foraminifera as trophic links between phytodetritus and benthic metazoans: carbon and nitrogen isotopic evidence
}

\author{
Hidetaka Nomaki ${ }^{1,{ }^{*}}$, Nanako O. Ogawa ${ }^{1}$, Naohiko Ohkouchi ${ }^{1}$, Hisami Suga ${ }^{1}$, \\ Takashi Toyofuku', Motohiro Shimanaga' ${ }^{2}$, Takeshi Nakatsuka ${ }^{3}$, Hiroshi Kitazato ${ }^{1}$ \\ ${ }^{1}$ Institute for Research on Earth Evolution, Japan Agency for Marine-Earth Science and Technology (JAMSTEC), 2-15, \\ Natsushima-cho, Yokosuka City, Kanagawa 237-0061, Japan \\ ${ }^{2}$ Aitsu Marine Station, Center for Marine Environment Studies, Kumamoto University, 6061 Aitsu, Matsushima-machi, \\ Kamiamakusa-shi, Kumamoto 861-6102, Japan \\ ${ }^{3}$ Institute of Low Temperature Science, Hokkaido University, Kita-19, Nishi-8, Kita-Ku, Sapporo 060-0819, Japan
}

\begin{abstract}
We examined the trophic levels of deep-sea benthic foraminifera and metazoans based on stable carbon and nitrogen isotopic compositions of soft tissue to evaluate the role of foraminifera in deep-sea benthic ecosystems. Living benthic foraminifera and metazoans were collected from 2 bathyal sites in Sagami Bay, Japan (water depths 750 and $1430 \mathrm{~m}$ ) on 3 occasions (April 2004, November 2004 and August 2005). Both carbon and nitrogen isotopic compositions significantly differed among the analysed foraminiferal species. At the deeper site $\delta^{15} \mathrm{~N}$ of the benthic foraminifera ranged from 6.7 to $11.0 \%$ (typically 7 to $10 \%$ ) with considerable interspecies variations. This implies that most benthic foraminifera utilize primarily surface sediments $(4.5 \%)$ or particulate organic matter $(6.4 \%)$ as their food sources. Many metazoan meiobenthic organisms, in particular polychaetes of meiofaunal size, some harpacticoid copepods, and kinorhynchs (examined only at the shallower site), exhibited $\delta^{15} \mathrm{~N}$ heavier than foraminifera, suggesting that they occupy higher trophic levels than benthic foraminifera. Macro- and megabenthos (spatangoids, ophiuroids and Dentalioida) exhibited $\delta^{15} \mathrm{~N}$ of 10 to $14 \%$, suggesting they belong in trophic levels 1 to 2 steps higher than metazoan meiobenthos and benthic foraminifera. Similar isotopic trends were observed at the shallower site. Combining the isotopic evidences and the observations on gut contents of some metazoan meiobenthos, together with previous experimental results, the benthic foraminifera in the bathyal Sagami Bay are considered a bridge in the energy flow from phytodetritus and sediments to metazoans.
\end{abstract}

KEY WORDS: Benthic foraminifera - Metazoan meiobenthos - Carbon isotopic composition · Nitrogen isotopic composition · Trophic level · Deep-sea food web · Foraminiferivory

\section{INTRODUCTION}

Knowledge of the trophic structures of benthic ecosystems are crucial to understanding elemental cycles on the seafloor, because predator-prey relationships control the energy flow among organisms. Phytodetritus and its degraded components form the basic energy and carbon sources that fuel benthic ecosystems. Within such ecosystems benthic foraminifera are commonly one of the most important consumers of fresh phytodetritus, especially in deep-sea settings (Moodley et al. 2002, Nomaki et al. 2005b). In field experiments at a continental shelf site, assimilation of phytodetritus by foraminifera was larger than that of bacteria (29.1 and $21.7 \%$, respectively) during $35 \mathrm{~h}$ incubation, although their biomass was only a fraction of that of bacteria (Moodley et al. 2002). At the same time benthic foraminifera are expected to be an important food for many metazoans living on the seafloor. Foraminiferivory, i.e. selective ingestion of foraminif- 
era (Hickman \& Lipps 1983), has been reported for various benthic organisms including polychaetes, neogastropods, gastropods, nematodes and isopods (Lipps \& Ronan 1974, Herbert 1991, Gudmundsson et al. 2000). In addition to selective ingestion, foraminifera may be ingested unselectively by many deep-sea animals through deposit feeding. These results suggest that benthic foraminifera are likely to constitute an important trophic pathway between phytodetritus and other meiofauna and macrofauna at the deep-sea floor. Despite their importance, the role of these organisms is poorly evaluated and this remains one of the major factors in deep-sea ecosystems limiting our understanding of geochemical cycling in these environments.

Carbon and nitrogen isotopic compositions of bulk organisms provide evidence for the food source and trophic level of organisms. Such isotopic analyses have successfully been applied to elucidate aquatic food web structures (Sullivan \& Moncreiff 1990, Yoshioka et al. 1994, Yoshii et al. 1999, Lovvorn et al. 2005, Yokoyama et al. 2005). Carbon isotopic compositions typically show minor enrichment in ${ }^{13} \mathrm{C}$ from resources to consumers (ca. 1\%o per trophic level; Vander Zanden \& Rasmussen 2001, McCutchan et al. 2003), thereby indicating the carbon source of analysed organisms. Nitrogen isotopic compositions are enriched in ${ }^{15} \mathrm{~N}$ by 3 to $4 \%$ from resources to consumers (DeNiro \& Epstein 1978, 1981, Minagawa \& Wada 1984), although the degree of enrichment varies among organisms (Vander Zanden \& Rasmussen 2001, McCutchan et al. 2003). Nitrogen isotopic compositions thus indicate the trophic level of the organism within the ecosystem. Dual isotopic analyses of benthic organisms therefore provide information about carbon and nitrogen sources and trophic level in the deep-sea benthic ecosystem.

Such analyses have scarcely been applied to benthic meiofauna (Carman \& Fry 2002, Moens et al. 2005) because the body mass of these taxa usually does not provide enough material for analysis. Therefore, the importance of metazoan meiofauna and foraminifera has often been neglected in the investigation of benthic food webs. As far as we know the only study applying this method to benthic foraminifera is Iken et al. (2001). They analyzed Rhizammina sp. and a mix (soft-walled test, mud-ball and agglutinated/calcareous test) of foraminiferal species to obtain sufficient mass for isotopic analyses. According to their results the benthic foraminifera had on average light nitrogen isotopic compositions, indicating that they are within a single trophic level of particulate organic matter (POM), whereas the $\delta^{15} \mathrm{~N}$ of nematodes, isopods and copepods was distinctly heavier. It can be concluded from these results that benthic foraminifera are primary consumers, ingesting phytodetritus directly. However, some of the duplicate samples exhibited up to $10 \%$ variability in $\delta^{15} \mathrm{~N}$, which covered roughly 3 trophic levels, probably due to the mix of different foraminiferal species. Variable feeding ecologies of benthic foraminifera have been observed both in nature and during experiments (Lee et al. 1966, Bernhard \& Bowser 1992, Goldstein \& Corliss 1994, Nomaki et al. 2006). Isotopic analyses of single foraminiferal species may provide precise trophic positions for each type in deep-sea benthic ecosystems.

Since 1992 faunal and ecological studies of benthic foraminifera have been conducted in the central part of Sagami Bay (water depth 1430 m), Japan (Kitazato \& Ohga 1995), and this was followed by integrated research on benthic-pelagic coupling involving organic matter depositions to the seafloor (Nakatsuka et al. 2003) and seasonal changes in abundances of bacteria, foraminifera and metazoan meiofauna (Kitazato et al. 2000, 2003, Shimanaga \& Shirayama 2000, Shimanaga et al. 2000, 2004). According to this series of research the benthic foraminifera and some metazoan meiofauna at this site utilize phytodetritus directly or indirectly as an energy source, and their isotopic compositions are thus expected to reflect those of primary consumers.

In the present study we determined carbon and nitrogen isotopic compositions of benthic organisms living at 2 bathyal sites in Sagami Bay, Japan. The isotopic compositions of various benthic organisms, including benthic foraminifera to metazoan meio-, macro-, and megafauna, were measured in 3 different seasons. In particular the isotopic compositions were determined at the species level of foraminifera to estimate their trophic level precisely. Trophic levels of each organism were determined, and benthic foraminiferal roles in the food web structure of the bathyal Sagami Bay were evaluated.

\section{MATERIALS AND METHODS}

Sediment and organism samples were collected from 2 bathyal stations of Sagami Bay (Stn SB: $1430 \mathrm{~m}$ and Stn G: 750 m; Fig. 1), Japan, during the RV 'Tanseimaru' cruise KT04-04 in April 2004, KT04-26 in November 2004 and KT05-18 in August 2005. Bottom water temperatures and salinities were $2.2^{\circ} \mathrm{C}$ and 34.6 at $\mathrm{Stn} \mathrm{SB}$ and $4.5^{\circ} \mathrm{C}$ and 34.4 at $\mathrm{Stn} \mathrm{G}$, respectively.

Surface sediments were collected with a box-corer and a Barnett-type multiple corer. The sediments taken by box-corer were used for macro- and megafaunal sampling. Surface sediments down to ca. $10 \mathrm{~cm}$ were sieved on $1 \mathrm{~mm}$ mesh using seawater immediately after collection. All visible specimens of 
macro- and megafauna (polychaetes, spatangoids, ophiuroids and Dentalioida) were picked up with forceps. Polychaetes and spatangoids were dissected to remove the digestive tract. After washing the samples using filtered seawater, they were frozen at $-80^{\circ} \mathrm{C}$ and then stored at $-20^{\circ} \mathrm{C}$ prior to sample processing in a laboratory.

The upper $5 \mathrm{~cm}$ of the sediments taken by the multiple-corer were immediately sliced into $0-2 \mathrm{~cm}$ and 2-5 cm sediment depths and then sieved on a $1 \mathrm{~mm}$ and $125 \mu \mathrm{m}$ mesh using filtered seawater. During the KT04-04 cruise, the sieved sediments were frozen at $-80^{\circ} \mathrm{C}$ and then stored at $-20^{\circ} \mathrm{C}$ prior to selection of meiofaunal samples in the laboratory. During both the KT04-26 and KT05-18 cruises, the sieved sediments were preserved by adding $\mathrm{AgCl}_{2}$. Both preservation methods do not contaminate samples with carbon or nitrogen, unlike fixing with formalin or ethanol. Bulk surface sediments were also sampled from the sediments collected by the multiple-corer and then kept frozen prior to further processing.

Water samples for measurements of POM in the benthic nepheloid layer were collected using a CTD/RMS system equipped with $10 \mathrm{l}$ Niskin bottles. They were filtered onboard onto pre-combusted $\left(450^{\circ} \mathrm{C}, 4 \mathrm{~h}\right)$ Whatman GF/F filters.

In the laboratory, metazoan meiofauna and benthic foraminifera whose test cavities were filled with active cytoplasm typical for living foraminifera were picked out from sediments $>125 \mu \mathrm{m}$ particle size fraction under a binocular stereoscopic microscope. Specimens of Cyclammina cancellata Brady, Uvigerina akitaensis Asano, Bolivina spissa Cushman, Globobulimina affinis (d'Orbigny) and Chilostomella ovoidea Reuss were selected for isotopic analyses from Stn SB. Specimens of Bulimina striata d'Orbigny, Bulimina subornata (Brady), Globobulimina spp. (G. affinis and Globobulimina pacifica Cushman) and $C$. ovoidea were selected for isotopic analyses from Stn G (Appendix 1 in MEPS electronic supplement; www.int-res.com/articles/suppl/ m357p153_app.pdf). Typically 50 to 300 specimens were prepared for each measurement of isotopic composition except for analyses of $C$. cancellata, for which 5 to 11 specimens per sample were prepared (Appendix 1). Metazoan meiofauna (nematodes, copepods, ostracods, Chaetodermatida, kinorhynchs, small bivalves and polychaetes) were also taken from the top $2 \mathrm{~cm}$ of the sediments between $125 \mu \mathrm{m}$ and $1 \mathrm{~mm}$ particle size fraction. Unlike benthic foraminifera most metazoan meiofauna were analyzed as mixtures of taxa to secure enough biomass for analyses. Both foraminifera and metazoan meiofauna were cleaned with artificial seawater to remove adhered particles.

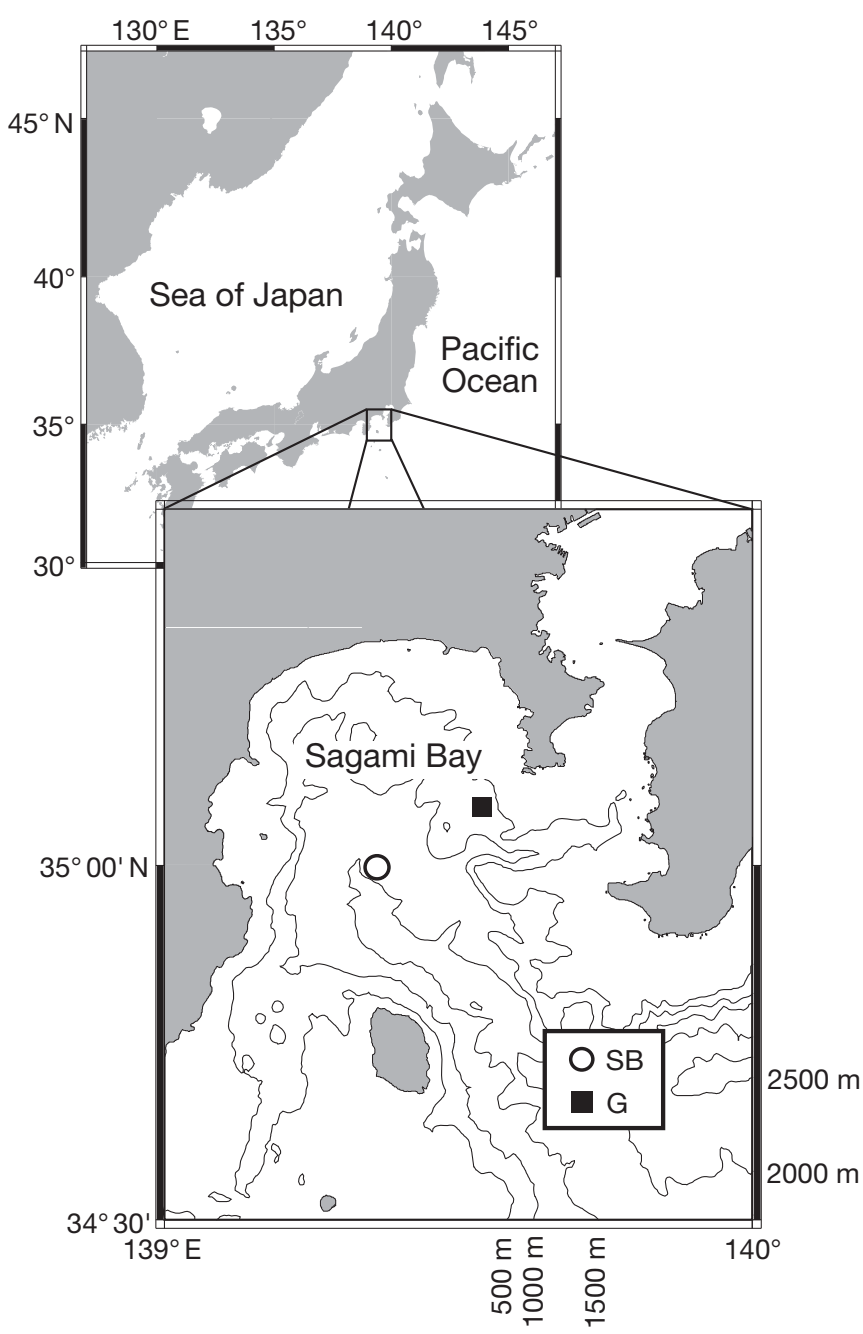

Fig. 1. Sampling sites $\mathrm{SB},\left(35^{\circ} 00^{\prime} \mathrm{N}, 139^{\circ} 22.5^{\prime} \mathrm{E}, 1430 \mathrm{~m}\right.$ water depth $)$ and $\mathrm{G},\left(35^{\circ} 05^{\prime} \mathrm{N}, 139^{\circ} 32.3^{\prime} \mathrm{E}, 750 \mathrm{~m}\right.$ water depth) in Sagami Bay, Japan

Frozen samples of macro- and megafauna were dried at $60^{\circ} \mathrm{C}$ and ground into powder samples. Bulk sediment samples were freeze-dried and ground into powder samples. The powdered samples, meiofaunal samples and filter samples for POM were weighed and transferred into silver cups, which had been prewashed with $\mathrm{MeOH}$ and dichloromethane $(1: 1, \mathrm{v} / \mathrm{v})$. Meiofaunal samples were transferred into silver cups and dried at $50^{\circ} \mathrm{C}$. All samples were decalcified with $2 \mathrm{~N} \mathrm{HCl}$, followed by drying on a hotplate. Dried silver cups containing decalcified samples were sealed into pre-cleaned tin cups prior to isotopic analysis. Carbon and nitrogen isotopic compositions, along with total organic carbon and nitrogen contents, were determined with an isotope ratio monitoring mass spectrometer (Delta plus XP, ThermoFinnigan) connected to an elemental analyzer (FlashEA1112, ThermoFinnigan). 
The isotope ratios were expressed by the $\delta$ notation as $\delta \mathrm{X}=\left[\left(\mathrm{R}_{\text {sample }} / \mathrm{R}_{\text {standard }}\right)-1\right] \times$ 1000 , where $X$ is ${ }^{13} \mathrm{C}$ or ${ }^{15} \mathrm{~N}$ and $\mathrm{R}$ is the ratio of ${ }^{13} \mathrm{C}:{ }^{12} \mathrm{C}$ or ${ }^{15} \mathrm{~N}:{ }^{14} \mathrm{~N}$. Vienna Pee Dee Belemnite for carbon and atmospheric $\mathrm{N}_{2}$ for nitrogen were used as standards. The inhouse standard of tyrosine $\left(\delta^{13} \mathrm{C}:-20.5 \%\right.$, $\delta^{15} \mathrm{~N}$ : $8.44 \%$ ) was used as a working standard. Analytical errors for the standards of $\delta^{13} \mathrm{C}$ and $\delta^{15} \mathrm{~N}$ were $\pm 0.2 \%$ and $\pm 0.4 \%$, respectively.

The foraminiferal isotopic data in the present study is expressed as an average value with standard deviation for replicate samples (typically 3 replicate samples; Appendix 1). Since different metazoan species were combined into a higher taxonomic group, specimens with different feeding habits could have been present in one sample. Therefore, isotopic data of these samples were not depicted seasonally.

\section{RESULTS}

\section{$\delta^{13} \mathrm{C}$ of foraminifera}

Average $\delta^{13} \mathrm{C}$ signatures differed among foraminiferal species at every site. On the other hand, $\delta^{13} \mathrm{C}$ signatures of most species were remarkably constant among different seasons.

At Stn SB carbon isotopic composition of foraminiferal species ranged from $-20.0 \pm$ $0.1 \%$ to $-18.3 \pm 0.1 \%$ (Fig. 2a, Appendix 1). The $\delta^{13} \mathrm{C}$ of foraminifera showed significant variability among species but little variability within most species. The lightest $\delta^{13} \mathrm{C}$ signatures were observed in Globobulimina affinis with a $\delta^{13} \mathrm{C}$ of $-20.0 \pm 0.1 \%$ to $-19.9 \%$. Relatively heavy $\delta^{13} \mathrm{C}$ was observed in Chilostomella ovoidea $(-19.9 \%$ o to $-18.3 \pm$ $0.1 \%)$ and in Cyclammina cancellata $(-18.7 \pm 0.1 \%$ to $-18.6 \pm 0.3 \%$ ) , although C. ovoidea exhibited a considerable seasonal variation. Uvigerina akitaensis and Bolivina spissa, which can both be categorized as phytophagous species (Nomaki et al. 2006), ranged from $-19.5 \pm 0.1 \%$ to $-19.1 \pm 0.1 \%$ and from $-19.6 \pm 0.2 \%$ to $-19.3 \pm 0.1 \%$, respectively.

At Stn G a similar trend was found for carbon isotopic compositions of Globobulimina and Chilostomella ovoidea, although the quantities in the measured sample were small (Fig. 2b). Carbon isotopic composition of Globobulimina spp. was depleted in ${ }^{13} \mathrm{C}$ with $-21.6 \%$. On the other hand, C. ovoidea exhibited the heaviest $\delta^{13} \mathrm{C}$ between $-18.8 \pm 0.1 \%$ and $-18.0 \pm$ $0.0 \%$ as well as at Stn SB. Values for $\delta^{13} \mathrm{C}$ in Bulimina striata and Bulimina subornata were $-19.3 \%$ and $-19.6 \%$, respectively, which are similar to those of phytophagous species from Stn SB.

At both stations Chilostomella ovoidea were enriched in ${ }^{13} \mathrm{C}$ by $0.6 \%$ to $0.8 \%$ (Stn G) and $0.8 \%$ to $1.6 \%$ (Stn SB) in August 2005 relative to the other sampling times. The other species exhibited constant $\delta^{13} \mathrm{C}$ values thoroughout the sampling periods.

\section{$\delta^{15} \mathrm{~N}$ of foraminifera}

There were substantial variations in $\delta^{15} \mathrm{~N}$ values among foraminiferal species, although most exhibited light isotopic compositions on average. At Stn SB rela- 


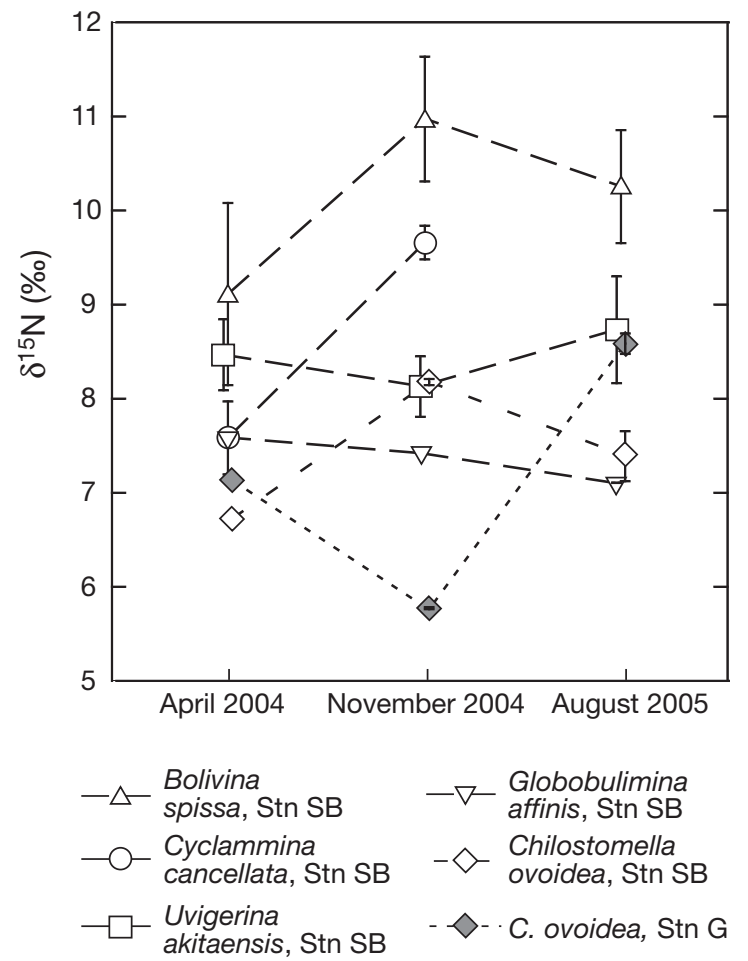

Fig. 3. Seasonal changes in nitrogen isotopic compositions (mean $\pm \mathrm{SD}$ ) of the 5 foraminiferal species from Stn SB and Chilostomella ovoidea from Stn G

tively light nitrogen isotopic compositions were obtained from Chilostomella ovoidea and Globobulimina affinis with $\delta^{15} \mathrm{~N}$ of $6.7 \%$ o to $8.2 \pm 0.0 \%$ and $7.1 \pm$ $0.0 \%$ to $7.6 \%$, respectively (Fig. 2). Bolivina spissa exhibited consistently heavy $\delta^{15} \mathrm{~N}$ with $9.1 \pm 1.0 \%$ to $11.0 \pm 0.7 \%$ o throughout the seasons (Fig. 3). Nitrogen isotopic compositions of Cyclammina cancellata (7.6 \pm $0.4 \%$ to $9.7 \pm 0.2 \%$ ) and Uvigerina akitaensis (8.1 \pm $0.3 \%$ o to $8.7 \pm 0.6 \%$ o) were relatively intermediate values. Compared to metazoan taxa, benthic foraminifera generally exhibited light nitrogen isotopic compositions (Fig. 4).

Distinct temporal variability was observed in $\delta^{15} \mathrm{~N}$ for some foraminiferal species (Fig. 3). Cyclammina cancellata, Bolivina spissa and Chilostomella ovoidea were enriched in ${ }^{15} \mathrm{~N}$ in November 2004 relative to those collected in April 2004 by 2.0, 1.9 and 1.5\%o, respectively. Both Globobulimina affinis and Uvigerina akitaensis showed a relatively constant $\delta^{15} \mathrm{~N}$, varying between 0.5 and $0.6 \%$.

At Stn G isotopic compositions of the benthic foraminifera were generally lighter ( 4.8 to $9.4 \%$ ) than those of metazoan meiofauna (Figs. 2 \& 4). Chilostomella ovoidea showed large seasonal variation from $5.8 \pm$ $0.0 \%$ in November 2004 to $8.6 \pm 0.1 \%$ in August 2005 (Fig. 3).
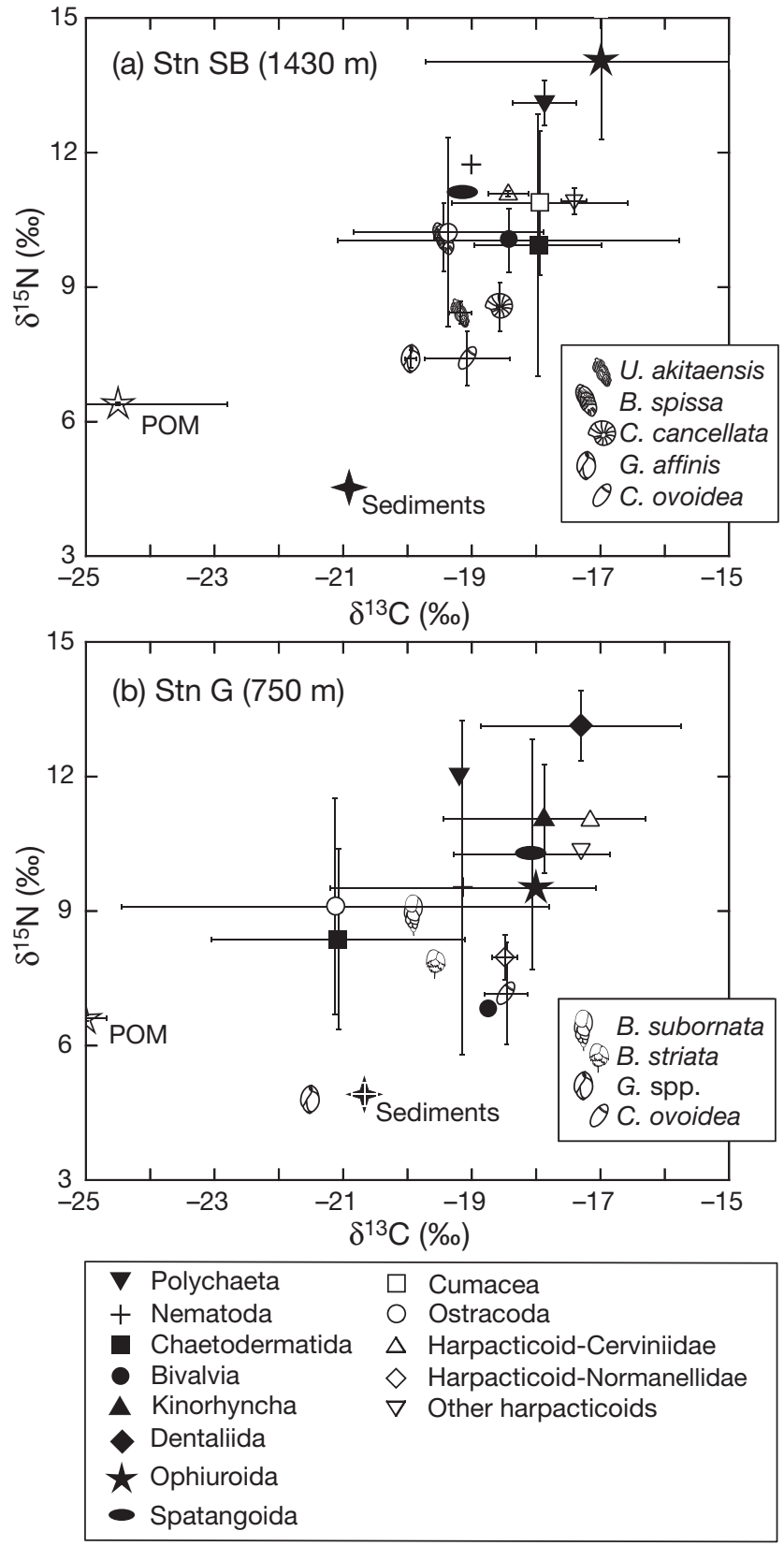

Fig. 4. Carbon and nitrogen isotopic compositions of metazoan meiobenthos. (a) Stn SB (water depth 1430 m), (b) Stn G (water depth $750 \mathrm{~m}$ ). Data are shown as a mean $( \pm 1 \mathrm{SD})$ through the sampling periods for each taxon. Data for benthic foraminifera and isotopic compositions of surface sediments and POM are also plotted. Full species names as in Fig. 2

\section{Isotopic composition of metazoan meiofauna}

Metazoan meiofauna exhibited $\delta^{13} \mathrm{C}$ from -19.3 to $-17.3 \%$ and -21.1 to $-17.2 \%$ at Stns SB and G, respectively (Fig. 4, Appendix 2 at www.int-res.com/ articles/suppl/m357p153_app.pdf). Within each taxon a large scatter of carbon isotopic compositions was observed. 
At Stn SB polychaetes exhibited $13.1 \pm 0.5 \%$ o $(\mathrm{n}=3)$ of nitrogen isotopic compositions, thereby containing the heaviest nitrogen isotopes among the studied metazoan meiofauna (Fig. 4). Nematodes (11.7\%, n = 5), Cerviniidae (Harpacticoida) (11.0 $\pm 0.1 \%, \mathrm{n}=2)$, other harpacticoid copepods $(10.9 \pm 0.3 \%$, $n=2)$ and cumaceans $(10.9 \pm 1.6 \%$ o, $\mathrm{n}=8)$ exhibited relatively heavy $\delta^{15} \mathrm{~N}$. Ostracods $(10.2 \pm 2.1 \%$, $\mathrm{n}=2)$, bivalves of meiofaunal size $(10.0 \pm 0.7 \%, \mathrm{n}=4)$ and Chaetodermatida $(8.8 \pm 2.9 \%$ o $\mathrm{n}=4)$ exhibited relatively light $\delta^{15} \mathrm{~N}$.

At Stn G metazoan meiofauna showed a nitrogen isotopic trend similar to those observed at Stn SB (Fig. 4). Polychaetes and cerviniids were enriched in ${ }^{15} \mathrm{~N}$ with $12.0 \%$ and $11.0 \%$, respectively, although only 1 sample was examined for each taxon. On the other hand, some specimens of bivalves, Chaetodermatida and ostracods exhibited light $\delta^{15} \mathrm{~N}$ that were similar to those of benthic foraminifera. Kinorhynchs, which were not measured at Stn SB, exhibited heavy $\delta^{15} \mathrm{~N}(11.0 \pm 1.1 \%$, $\mathrm{n}=5)$ in addition to polychaetes and cerviniids. Among the harpacticoid copepods, Normanellidae $(8.0 \pm 1.1 \%$, $\mathrm{n}=2)$ were depleted in ${ }^{15} \mathrm{~N}$ by 2.4 to $2.9 \%$ relative to Cerviniidae and other harpacticoid copepods. All metazoan meiofauna from Stn G were depleted in ${ }^{15} \mathrm{~N}$ by 0.1 to $3.2 \%$ o (1.7\%o avg.) relative to same taxa from Stn SB (Fig. 4).

\section{Isotopic compositions of metazoan macro- and megafauna}

At Stn SB ophiuroids exhibited $13.7 \pm 1.9 \%$ 。 of $\delta^{15} \mathrm{~N}$, which is the heaviest mean $\delta^{15} \mathrm{~N}$ value among examined animals at this site (Fig. 4). Those of spatangoids were $10.1 \pm 0.4 \%$.

At Stn G ophiuroids exhibited light nitrogen isotopic compositions $(9.4 \pm 0.2 \%$ ) relative to Stn SB. Spatangoids displayed a large scatter in $\delta^{15} \mathrm{~N}$ values among individuals with an average of $9.9 \pm 2.5 \%$. Dentalioida, which were not found at Stn SB, exhibited heavy $\delta^{15} \mathrm{~N}(13.1 \pm 0.8 \%)$.

\section{Isotopic compositions of bulk surface sediment and POM samples}

Carbon and nitrogen isotopic compositions of bulk surface sediments were $-20.8 \%$ and $4.5 \%$, respectively, at Stn SB in April 2004. Those at Stn G were $-20.6 \pm 0.1 \%$ and $5.0 \pm$ $0.3 \%$ in April 2004 and $-20.8 \pm 0.1 \%$ and 4.9 $\pm 0.2 \%$ in November 2004, respectively.
POM in the benthic nepheloid layer showed a constant $\delta^{15} \mathrm{~N}$, while $\delta^{13} \mathrm{C}$ varied between April and November 2004. At Stn SB $\delta^{15} \mathrm{~N}$ of POM was $6.4 \%$ in April and $6.3 \%$ in November. Unlike $\delta^{15} \mathrm{~N}, \delta^{13} \mathrm{C}$ of POM displayed values of $-22.8 \%$ and $-26.2 \%$ in April and November, respectively. At Stn $\mathrm{G} \delta^{13} \mathrm{C}$ of POM also exhibited a relatively large difference between seasons (-24.8\% in April and $-25.5 \%$ in November) relative to $\delta^{15} \mathrm{~N}$ (6.5\% in April and 6.7\% in November).

\section{$\mathrm{C} / \mathrm{N}$ ratio}

The $\mathrm{C} / \mathrm{N}$ ratios of foraminifera showed substantial differences between both species and seasons (Fig. 5, Appendix 1). At $\mathrm{Stn} \mathrm{SB}$ the $\mathrm{C} / \mathrm{N}$ ratio was relatively low for Chilostomella ovoidea and ranged from 3.4 to $4.2 \pm 0.0$. The other species exhibited a $\mathrm{C} / \mathrm{N}$ ratio of $4.4 \pm 0.3$ to $6.1 \pm 0.0$. Among the same species $\mathrm{C} / \mathrm{N}$ ratios in April 2004 were low compared to other sampling seasons. In the case of shallow infaunal species (Cyclammina cancellata, Uvigerina akitaensis and Bolivina spissa), C/N ratios in April 2004 were lower than other seasons by 0.9 to1.5. Seasonal offset was small as 0.2 to 0.7 in the case of Globobulimina affinis.

At Stn G Chilostomella ovoidea also exhibited a low $\mathrm{C} / \mathrm{N}$ ratio compared to other species, ranging from 3.1 to $4.1 \pm 0.2$. The other 3 species exhibited $\mathrm{C} / \mathrm{N}$ ratios similar to those from $\mathrm{Stn} \mathrm{SB}$, ranging from 4.7 to 6.2 . A seasonal change in the $\mathrm{C} / \mathrm{N}$ ratio was also observed for

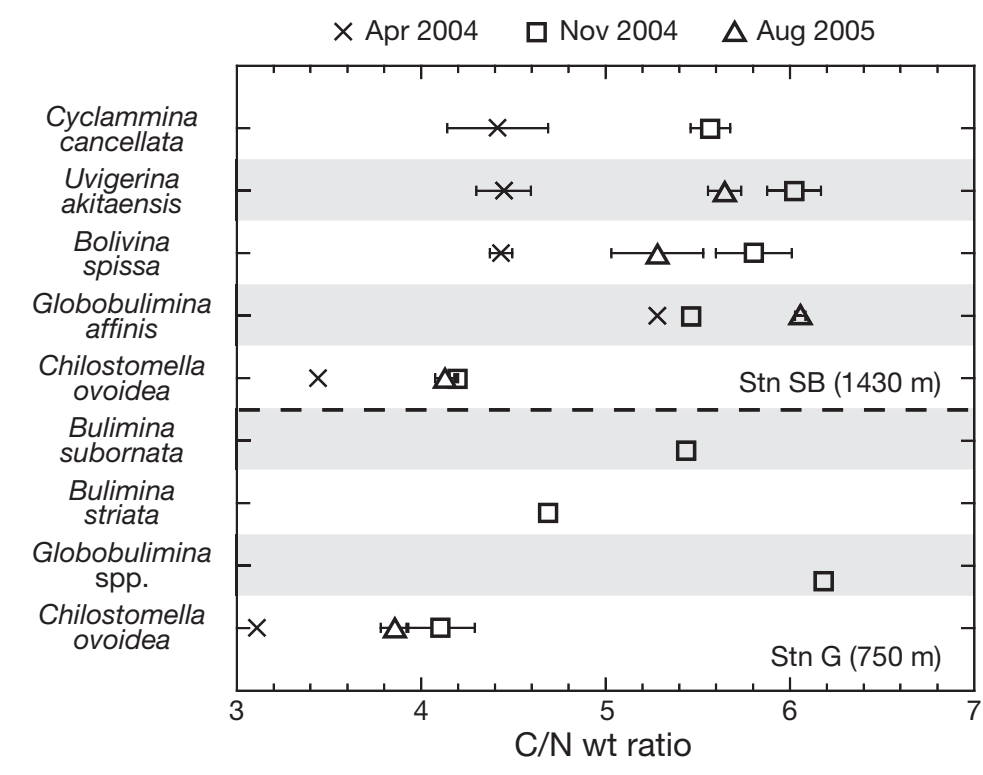

Fig. 5. C/N ratios of benthic foraminifera and their seasonal changes at Sagami Bay 
C. ovoidea, which is the only species examined in different seasons at $\mathrm{Stn}$ G. C/N ratio of C. ovoidea in April 2004 was 0.8 and 1.0 lower than those of November 2004 and August 2005, respectively. This is similar to seasonal differences of C. ovoidea at Stn SB.

The $\mathrm{C} / \mathrm{N}$ ratios of metazoan meiobenthos at Stn SB generally ranged from ca. 4 to 5 except for ostracods (Appendix 2). Those at Stn G were generally lower than Stn SB and ranged from ca. 3 to 4 with maxima of 5.1 in the polychaete sample.

Bulk surface sediment exhibited $\mathrm{C} / \mathrm{N}$ ratios of 7.8 and $8.0 \pm 0.2$ at Stns $\mathrm{SB}$ and $\mathrm{G}$, respectively. POM exhibited a relatively large scatter in $\mathrm{C} / \mathrm{N}$ ratios with $7.3 \pm 1.9$ at $\mathrm{Stn} \mathrm{SB}$ and $10.5 \pm 0.4$ at $\mathrm{Stn} \mathrm{G}$.

\section{DISCUSSION}

\section{$\delta^{15} \mathrm{~N}$ variation of food sources}

Temporal variations in $\delta^{15} \mathrm{~N}$ of food sources may account for part of the variation observed in the results described above. In the present study $\delta^{15} \mathrm{~N}$ of POM and surface sediments were determined to evaluate the potential food of benthic organisms. Nitrogen isotopic compositions of POM varied both vertically within the water column (due to preferential degradation of ${ }^{15} \mathrm{~N}$-enriched compounds in sinking particles; Nakatsuka et al. 1997) and seasonally (caused by changes in the nutrient budget in the surface ocean; Nakatsuka \& Handa 1997). Sinking particles adjacent to Stn SB obtained from sediment traps moored at 20 and $350 \mathrm{~m}$ above bottom (mab) in 2001 displayed a seasonal fluctuation in $\delta^{15} \mathrm{~N}$ (T. Nakatsuka unpubl. data). The $\delta^{15} \mathrm{~N}$ of sinking particles at 350 mab fluctuated seasonally with lighter values in winter and spring (min. of $3.2 \%$ ) and heavier values in summer and autumn (max. of $6.5 \%$ ). Those at 20 mab did not exhibit such a clear seasonal trend due to the existence of rebounded particles (Nakatsuka et al. 2003). These temporal changes may affect the measured $\delta^{15} \mathrm{~N}$ values in our samples. The extent of the effects may well differ among organisms, depending on differences in their trophic positions and turnover rates of body tissues.

The nitrogen isotopic composition of sedimentary organic matter is also altered due to microbial degradation of organic matter (Freudenthal et al. 2001, Lehmann et al. 2002). Sediment samples from Stn G exhibited slightly variable $\delta^{15} \mathrm{~N}$ through sampling depth within each season, between 4.6 and $5.3 \%$ in April 2004 and 4.7 and 5.2\%o in November 2004 (Fig. 2), although the variability was not large in comparison with the $\delta^{15} \mathrm{~N}$ enrichments per trophic level.

\section{Trophic relationships and the role of foraminifera}

Nitrogen isotopic compositions of foraminifera typically ranged from 7 to $10 \%$ at Stn SB (Figs. 2 \& 3). Although seasonal and interspecies variations were observed, benthic foraminifera were enriched in ${ }^{15} \mathrm{~N}$ relative to surface sediments $(4.5 \%$ o) and POM $(6.4 \%)$.

The tissues of an organism are enriched in ${ }^{15} \mathrm{~N}$ from resources to consumers by 3 to $4 \%$, but the degree of enrichment varies largely among organisms (Vander Zanden \& Rasmussen 2001, McCutchan et al. 2003). Increases in bulk $\delta^{15} \mathrm{~N}$ with trophic shift reflect an averaging of large increases in the $\delta^{15} \mathrm{~N}$ of alanine and glutamic acid during transamination and deamination (Macko et al. 1986), no change of phenylalanine, serine and tyrosine and little change in others (McClelland \& Montoya 2002, Chikaraishi et al. 2007). Consequently, ${ }^{15} \mathrm{~N}$ enrichment of bulk tissues can vary according to their biochemical composition having different $\delta^{15} \mathrm{~N}$. As a whole, however, generally $3 \%$ of isotopic shift was observed in the case of marine invertebrates from food sources to consumers (Vander Zanden \& Rasmussen 2001, Post 2002, McCutchan et al. 2003).

The amplitude of ${ }^{15} \mathrm{~N}$-enrichment in the foraminifera presented in the present study corresponds to a difference of ca. 1 trophic level (3 to $4 \%$ ) from surface sediments and POM, suggesting that benthic foraminifera primarily ingest and digest these materials. This supports previous claims that benthic foraminifera are among the primary consumers at the deep-sea floor, as suggested by faunal analyses (Gooday \& Turley 1990, Kitazato et al. 2000) and feeding experiments (Altenbach 1992, Moodley et al. 2002). The carbon isotopic compositions do not contradict the view that surface sediments and POM are likely to be the major carbon sources for benthic foraminifera.

Despite large variations in $\delta^{13} \mathrm{C}$ and $\delta^{15} \mathrm{~N}$ within taxon at any site, metazoan meiobenthos generally exhibited $\delta^{15} \mathrm{~N}$ signatures heavier than foraminifera (Fig. 4). The variations are likely to be caused by the fact that species with different feeding habits were combined prior to analysis. Among metazoan meiofauna collected from Stns SB and G, some specimens of Chaetodermatida, ostracods and bivalves were depleted in ${ }^{15} \mathrm{~N}$ relative to other metazoan meiofauna. These taxa may occupy a lower trophic level in which they ingest POM or surface sediments like the benthic foraminifera. Large variations in $\delta^{13} \mathrm{C}$ values among taxa were found (Fig. 4), suggesting that a variety of feeding habits is present within a taxon. Other metazoan meiobenthos, polychaetes, nematodes, cumaceans, cerviniids and other harpacticoid copepods exhibited relatively heavy $\delta^{15} \mathrm{~N}$ values at Stn SB. Their $\delta^{15} \mathrm{~N}$ compositions were 6.5 to $8.5 \%$, 4.5 to $5.5 \%$ and 
ca. 2 to $5 \%$ heavier than those of surface sediments, POM and benthic foraminifera, respectively. These enrichments in ${ }^{15} \mathrm{~N}$ may imply that these metazoan meiofauna feed on benthic foraminifera and other primary consumers, or on a mix of them. Carbon isotopic compositions of these metazoans support this conclusion. Like at Stn SB polychaetes and cerviniids exhibited $\delta^{15} \mathrm{~N}$ signatures heavier than foraminifera at Stn G.
Many benthic organisms are known to ingest foraminifera based on direct observation of their gut contents (Lipps \& Ronan 1974, Hickman \& Lipps 1983, Herbert 1991, Gudmundsson et al. 2000). At Stn SB we observed several foraminiferal specimens within the gut contents of harpacticoid copepods and polychaetes. Benthic foraminifera (probably Suggrunda sp. and some Rotaliina species) were observed in the gut
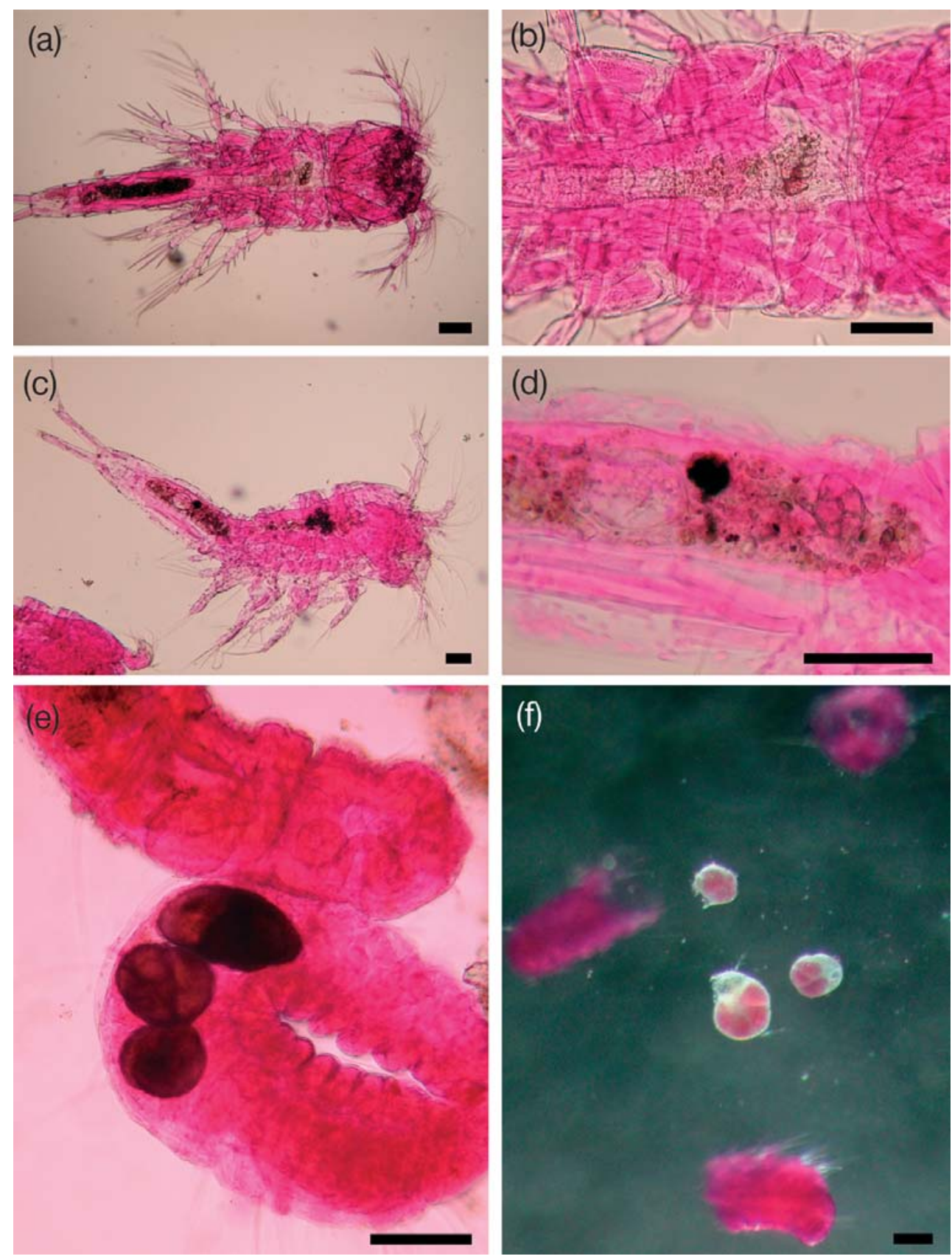

Fig. 6. Benthic foraminiferal specimens found in gut contents of metazoan meiobenthos. (a,b) Suggrunda sp.? found from cerviniids (harpacticoid copepods), (c,d) Rotaliina species found from cerviniids, (e,f) Globobulimina sp. and some Rotaliina species found from polychaetes. (b) and (d) are the same specimens as in (a) and (c), respectively. All specimens were collected from Stn SB. Scale bars $=100 \mu \mathrm{m}$ 
of cerviniids collected at Stn SB (Fig. 6a-d). Polychaete specimens that had ingested Globobulimina sp. and some Rotaliina species were also found at Stn SB (Fig. 6e,f). Nitrogen isotopic compositions of cerviniids and polychaete in the present study $(11.0 \%$ and $13.1 \%$ $\pm 0.5 \%$, respectively) were enriched in ${ }^{15} \mathrm{~N}$ by 1 to $4 \%$ o and 3 to $6 \%$ relative to foraminifera, implying that the foraminifera found in the gut contents were utilized as their energy source. Low $\mathrm{C} / \mathrm{N}$ ratios of benthic foraminifera (Fig. 5) suggest that they would serve as valuable nutritional sources for benthic metazoan organisms. Other metazoans also exhibited heavy $\delta^{15} \mathrm{~N}$ values ranging from 9 to $12 \%$, suggesting that many metazoan meiofauna also may utilize primary consumers, including benthic foraminifera alone, or in a mix with sediments/POM at Stn SB. The high abundances and biomass of foraminifera at the sampled stations (Nomaki et al. 2005b), together with their presence in the gut contents, make it likely that foraminiferal isotopic compositions are to a large extent responsible for the observed isotopic composition of the metazoans. Consequently, it may well be that foraminiferal abundances in surface sediments affect the distribution, growth and reproduction of those metazoan species.

Some metazoan macro- to megabenthos exhibited further heavier $\delta^{15} \mathrm{~N}$ signatures (max. of $17 \%$ in ophiuroids) than metazoan meiobenthos. They are thought to possess one or more trophic levels higher than metazoan meiofauna and foraminifera. Among the measured samples in the present study, the heavi- est $\delta^{15} \mathrm{~N}$ signature were found in ophiuroids at Stn SB. Ophiuroids are known to have a variety of feeding habits, including predation and scavenging, as well as deposit- and suspension-feeding (Herring 2002). Their carbon and nitrogen isotopic compositions imply that they are predators of meio- and macrobenthos in this area.

Some foraminiferal species are known to feed on phytodetritus or surface sediments (Gooday 1988, Goldstein \& Corliss 1994, Nomaki et al. 2006). It has also been reported that foraminifera are important food sources for metazoans, since they are found in their gut contents (Hickman \& Lipps 1983). Our results confirm the position of foraminifera in both respects, i.e. consuming POM/sediment and being consumed by metazoans. Carbon isotopic compositions and observations on gut contents further confirm these trophic interactions. In summary, phytodetritus is ingested by benthic foraminiferal species and foraminifera are then digested by metazoan meiobenthos like harpacticoids and polychaetes. Macro- and megabenthos like ophiuroids and Dentalioida may ingest some metazoan meiobenthos (Fig. 7).

\section{Variability in foraminiferal isotopic compositions}

We observed a considerable variability in carbon and nitrogen isotopic compositions among foraminiferal species and sampling seasons. This shows that species-level measurements of isotopic compositions

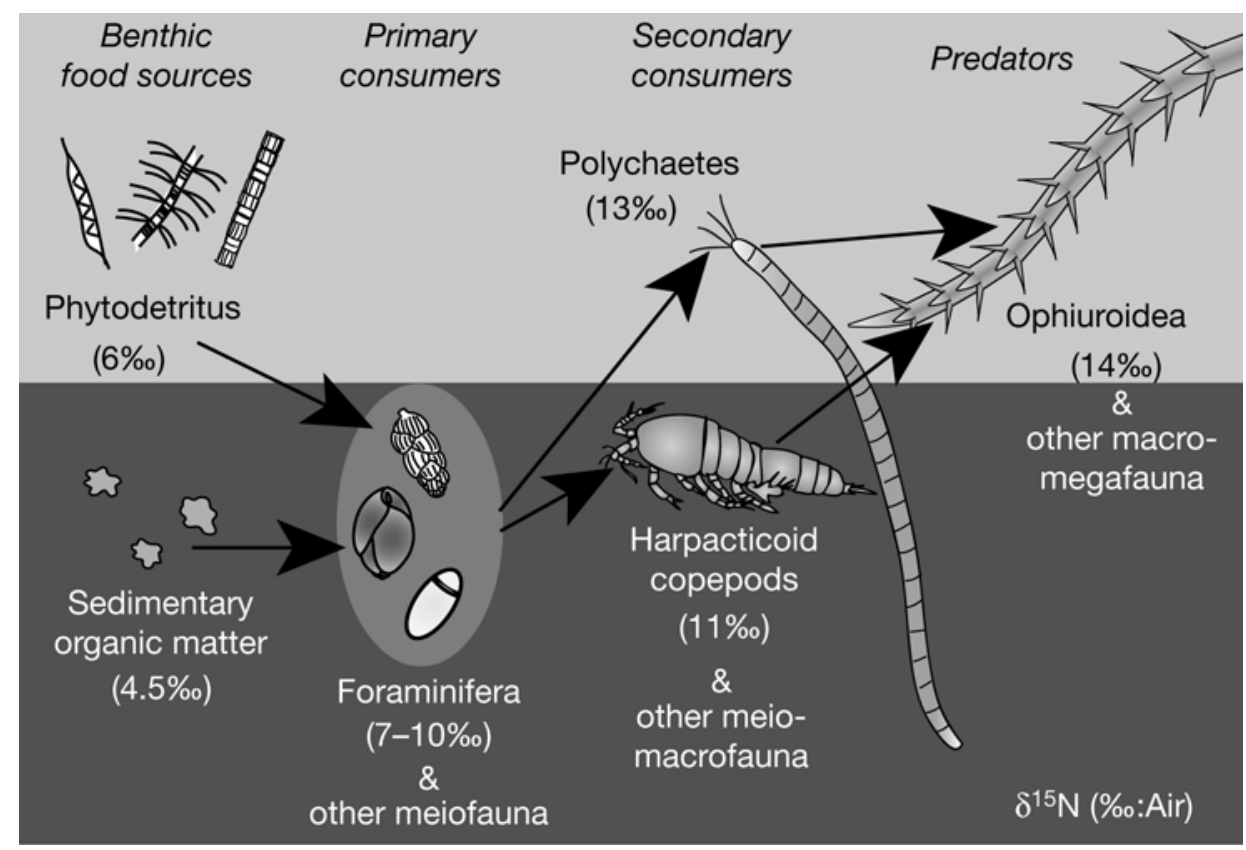

Fig. 7. Food web structures in the bathyal Sagami Bay suggested by carbon and nitrogen isotopic compositions. Nitrogen isotopic values are examples from Stn SB 
are useful for understanding feeding ecology and trophic relationships of species.

In the present study $\delta^{13} \mathrm{C}$ of the foraminifera were concordant to different feeding behaviors as suggested by Nomaki et al. (2006). Deposit feeders (Cyclammina cancellata and Chilostomella ovoidea) were enriched in ${ }^{13} \mathrm{C}$ relative to both phytophagous (Uvigerina akitaensis and Bolivina spissa) and seasonal-phytophagous species (Globobulimina affinis; Figs. 2 \& 4). Since the $\delta^{13} \mathrm{C}$ of POM is depleted in ${ }^{13} \mathrm{C}$ relative to surface sediment (Fig. 2), variations among species may be caused by different food sources. However, one should bear in mind that the $\delta^{13} \mathrm{C}$ of sinking organic particles changes seasonally from $-23 \%$ to $-19 \%$, covering the range of seasonal variation in those of surface sediment (-20.8 to $-20.0 \%$; Nakatsuka et al. 2003).

Alternatively, some variations in $\delta^{15} \mathrm{~N}$ were observed within the group having the same feeding behavior suggested by experimental study. In particular, Bolivina spissa was enriched in ${ }^{15} \mathrm{~N}$ relative to Uvigerina akitaensis by up to $2.8 \%$, roughly corresponding to the ${ }^{15} \mathrm{~N}$ enrichment per trophic level. In addition, B. spissa exhibited a maximum seasonal shift of $1.9 \%$ in $\delta^{15} \mathrm{~N}$, whereas the shift in $U$. akitaensis was only $0.6 \%$. A potential explanation for this difference in $\delta^{15} \mathrm{~N}$ is that the 2 species utilize different types or grades of phytodetritus. Contrary to the experiments by Nomaki et al. (2006), in which 2 algal species were used as food sources for the experiment, phytodetritus naturally contain various types of phytoplankton (Billett et al. 1983, Smith et al. 1996, de Wilde et al. 1998). Although $U$. akitaensis and B. spissa fed on the same algae in experiments, it is possible that in nature they feed on different kinds of algae possibly having different $\delta^{15} \mathrm{~N}$ signatures due to variable ${ }^{15} \mathrm{~N}$ fractionations (Montoya \& McCarthy 1995).

In addition, a difference in the speed of uptake of ${ }^{13} \mathrm{C}$ labeled Dunaliella (Nomaki et al. 2005b) indicates that the difference in the isotopic compositions of these 2 species could be caused by alteration of the food's isotopic composition before ingestion by the foraminifera. The seasonal enrichment in ${ }^{15} \mathrm{~N}$ of Bolivina spissa from April to November (Fig. 3) might indicate that they could have utilized fresh phytodetritus in spring when plenty of fresh phytodetritus existed and degraded phytodetritus in autumn when the fresh phytodetritus was limited (Kitazato et al. 2003). In contrast, Uvigerina akitaensis might exclusively utilize the fresh phytodetritus from the ocean surface throughout the season.

It is notable that both the tracer experiment and stable isotope approach represent discrete aspects of the feeding ecology. Natural isotopic compositions represent a time-integrated diet of animals in nature. However, results obtained from natural isotopic com- positions sometimes show blurred results because of the complex trophic interaction between the organisms and trophic omnivory that are prevalent in many ecosystems. On the other hand, tracer feeding experiments represent the feeding ecology of organisms under specific, controlled conditions. In the present study natural isotopic compositions represented the possibility of different food sources within the same feeding habits, which was suggested by in situ experimental studies. Discordance between natural isotopic signatures and results of isotopic tracer experiments were also reported for nematodes (Carman \& Fry 2002). A combination of both methods, each with its advantages, will clarify variable trophic ecology of foraminifera. Using natural tracers that are specific for a taxon may well be an effective method to elucidate their feeding ecology (Suhr et al. 2003, Ward et al. 2003). Further investigations of interspecies and seasonal variation in diets will provide important insight into the structure of benthic food webs and organic matter cycling.

\section{Trophic levels and seasonal reproduction at the deep-sea floor}

At Stn SB benthic foraminifera are known to show seasonal variation in their abundance (Kitazato et al. 2000). Similar seasonal variations have been reported for benthic foraminifera in different oceanic settings (reviewed by Gooday 2002). According to feeding experiments benthic foraminifera reproduce shortly after artificial phytodetritus depositions (Heinz et al. 2001, 2002, Nomaki et al. 2005a). Since most benthic foraminiferal species possess a lower trophic position (Fig. 4), an increase in abundance is likely to follow this period of reproduction. The seasonal trend in $\mathrm{C} / \mathrm{N}$ ratios, with low values in April (Fig. 5) when phytodetritus arrive on the seafloor (Nakatsuka et al. 2003), supports quick ingestion of fresh, nutrition-rich organic matter by foraminifera.

Abundances of metazoan meiobenthos do not correlate well to the arrival of phytodetritus, while foraminiferal abundances do correlate to this arrival at the seafloor in Sagami Bay (Shimanaga \& Shirayama 2000). Unpronounced seasonality of the metazoan meiobenthos in relation to phytodetritus deposition was also shown in the review by Gooday (2002). It may reflect slower rates of somatic growth and their energy requirements for egg production (Soltwedel 2000). It may also relate to their higher trophic level compared to benthic foraminifera (Fig. 4). Effects of nutritional inputs as phytodetritus from the water column to the deep-sea floor may be mediated or retarded by passing through lower trophic levels to higher. Galéron et al. 
(2001) reported that abundances of meiofaunal polychaetes and foraminifera increased seasonally after a phytodetritus deposition event at the Porcupine Abyssal Plain $(4850 \mathrm{~m})$. In contrast, polychaetes of macrofaunal size showed a lagged response to the same event by slowly increasing in abundance. It was concluded that foraminifera and meiofaunal polychaetes increased rapidly because they are primary consumers of phytodetritus. Although meiofaunal polychaetes in the present study exhibited heavy $\delta^{15} \mathrm{~N}$, it may be common that primary consumers of meiofaunal size class can increase quickly after a phytodetritus supply, thus resulting in a pronounced seasonality in their abundances at the deep-sea floor.

Acknowledgements. We thank the crew of RV 'Tanseimaru' for their operations on seawater and sediment samplings onboard. We also thank S. Sakai, K. Oguri and K. Iijima for their help with onboard sampling. We are grateful to L. de Nooijer for his comments and Y. Chikaraishi for his suggestions and discussion. H. Horikawa provided the bathymetrical map of Sagami Bay. We appreciate the comments of the editor and 2 anonymous reviewers. This research was financially supported by the Japan Society for the Promotion of Science to H.N. (No. 16-11027), to N.O.O. (No. 17770025), to H.K (No. 14340156 and No. 17204046) and CREST, JST to N.O.O.

\section{LITERATURE CITED}

Altenbach AV (1992) Short-term processes and patterns in the foraminiferal response to organic flux rates. Mar Micropaleontol 19:119-129

Bernhard JM, Bowser SS (1992) Bacterial biofilms as a trophic resource for certain benthic foraminifera. Mar Ecol Prog Ser 83:263-272

Billett DSM, Lampitt RS, Rice AL, Mantoura RFC (1983) Seasonal sedimentation of phytoplankton to the deep-sea benthos. Nature 302:520-522

- Carman KR, Fry B (2002) Small-sample methods for $\delta^{13} \mathrm{C}$ and $\delta^{15} \mathrm{~N}$ analysis of the diets of marsh meiofaunal species using natural-abundance and tracer-addition isotope techniques. Mar Ecol Prog Ser 240:85-92

> Chikaraishi Y, Kashiyama Y, Ogawa NO, Kitazato H, Ohkouchi N (2007) Metabolic control of nitrogen isotope composition of amino acids in macroalgae and gastropods: implications for aquatic food web studies. Mar Ecol Prog Ser 342:85-90

de Wilde PAWJ, Duineveld GCA, Berghuis EM, Lavaleye MSS, Kok A (1998) Late-summer mass deposition of gelatinous phytodetritus along the slope of the NW European Continental Margin. Prog Oceanogr 42:165-187

DeNiro MJ, Epstein S (1978) Influence of diet on the distribution of carbon isotopes in animals. Geochim Cosmochim Acta 42:495-506

DeNiro MJ, Epstein S (1981) Influence of diet on the distribution of nitrogen isotopes in animals. Geochim Cosmochim Acta 45:341-351

Freudenthal T, Wagner T, Wenzhöfer F, Zabel M, Wefer G (2001) Early diagenesis of organic matter from sediments of the eastern subtropical Atlantic: evidence from stable nitrogen and carbon isotopes. Geochim Cosmochim Acta 65:1795-1808
Galéron J, Sibuet M, Vanreusel A, Mackenzie K, Gooday AJ, Dinet A, Wolff GA (2001) Temporal patterns among meiofauna and macrofauna taxa related to changes in sediment geochemistry at an abyssal NE Atlantic site. Prog Oceanogr 50:303-324

Goldstein ST, Corliss BH (1994) Deposit feeding in selected deep-sea and shallow-water benthic foraminifera. DeepSea Res I 41:229-241

Gooday AJ (1988) A response by benthic foraminifera to the deposition of phytodetritus in the deep sea. Nature 332: $70-73$

Gooday AJ (2002) Biological responses to seasonally varying fluxes of organic matter to the ocean floor: a review. J Oceanogr 58:305-332

Gooday AJ, Turley CM (1990) Responses by benthic organisms to inputs of organic material to the ocean floor: a review. Philos Trans R Soc Lond A 331:119-138

> Gudmundsson G, von Schmalensee M, Svavarsson J (2000) Are foraminifers (protozoa) important food for small isopods (Crustacea) in the deep sea? Deep-Sea Res I 47 : 2093-2109

Heinz P, Kitazato H, Schmiedl G, Hemleben C (2001) Response of deep-sea benthic foraminifera from the Mediterranean sea to simulated phytoplankton pulses under laboratory conditions. J Foram Res 31:210-227

Heinz P, Hemleben C, Kitazato H (2002) Time-response of cultured deep-sea benthic foraminifera to different algal diets. Deep-Sea Res I 49:517-537

- Herbert DG (1991) Foraminiferivory in a Puncturella (Gastropoda: Fissurellidae). J Mollusc Stud 57:127-129

Herring P (2002) The biology of the deep ocean. Oxford University Press, New York

Hickman CS, Lipps JH (1983) Foraminiferivory: selective ingestion of foraminifera and test alterations produced by the neogastropod Olivella. J Foram Res 13:108-114

Iken K, Brey T, Wand U, Voigt J, Junghans P (2001) Food web structure of the benthic community at the Porcupine Abyssal Plain (NE Atlantic): a stable isotope analysis. Prog Oceanogr 50:383-405

Kitazato H, Ohga T (1995) Seasonal changes in deep-sea benthic foraminiferal populations: results of long-term observations at Sagami Bay, Japan. In: Sakai H, Nozaki Y (eds) Biogeochemical processes and ocean flux in the western Pacific. Terra Scientific Publishing Company, Tokyo, p 331-342

Kitazato H, Shirayama Y, Nakatsuka T, Fujiwara S and others (2000) Seasonal phytodetritus deposition and responses of bathyal benthic foraminiferal populations in Sagami Bay, Japan: preliminary results from 'Project Sagami 1996-1999'. Mar Micropaleontol 40:135-149

Kitazato H, Nakatsuka T, Shimanaga M, Kanda J and others (2003) Long-term monitoring of the sedimentary processes in the central part of Sagami Bay, Japan: rationale, logistics and overview of results. Prog Oceanogr 57:3-16

Lee JJ, McEnery M, Pierce S, Freudenthal HD, Muller WA (1966) Tracer experiments in feeding littoral foraminifera. J Protozool 13:659-670

Lehmann MF, Bernasconi SM, Barbieri A, McKenzie JA (2002) Preservation of organic matter and alteration of its carbon and nitrogen isotope composition during simulated and in situ early sedimentary diagenesis. Geochim Cosmochim Acta 66:3573-3584

Lipps JH, Ronan TE Jr (1974) Predation on foraminifera by the polychaete worm Diopatra. J Foram Res 4:139-143

Lovvorn JR, Cooper LW, Brooks ML, De Ruyck CC, Bump JK, Grebmeier JM (2005) Organic matter pathways to zooplankton and benthos under pack ice in late winter and 
open water in late summer in the north-central Bering Sea. Mar Ecol Prog Ser 291:135-150

Macko SA, Fogel-Estep ML, Engel MH, Hare PE (1986) Kinetic fractionation of stable nitrogen isotopes during amino acid transamination. Geochim Cosmochim Acta 50:2143-2146

McClelland JW, Montoya JP (2002) Trophic relationships and the nitrogen isotopic composition of amino acids in plankton. Ecology 83:2173-2180

McCutchan JH Jr, Lewis WM Jr, Kendall C, McGrath CC (2003) Variation in trophic shift for stable isotope ratios of carbon, nitrogen and sulfur. Oikos 102:378-390

Minagawa M, Wada E (1984) Stepwise enrichment of ${ }^{15} \mathrm{~N}$ along food chains: further evidence and the relation between $\delta^{15} \mathrm{~N}$ and animal age. Geochim Cosmochim Acta 48:1135-1140

Moens T, Bouillon S, Gallucci F (2005) Dual stable isotope abundances unravel trophic position of estuarine nematodes. J Mar Biol Assoc UK 85:1401-1407

Montoya JP, McCarthy JJ (1995) Isotopic fractionation during nitrate uptake by phytoplankton grown in continuous culture. J Plankton Res 17:439-464

Moodley L, Middelburg JJ, Boschker HTS, Duineveld GCA, Pel R, Herman PMJ, Heip CHR (2002) Bacteria and foraminifera: key players in a short-term deep-sea benthic response to phytodetritus. Mar Ecol Prog Ser 236: 23-29

Nakatsuka T, Handa N (1997) Reconstruction of seasonal variation in nutrient budget of a surface mixed layer using $\delta^{15} \mathrm{~N}$ of sinking particle collected by a time-series sediment trap system. J Oceanogr 53:105-116

Nakatsuka T, Handa N, Harada N, Sugimoto T, Imaizumi S (1997) Origin and decomposition of sinking particulate organic matter in the deep water column inferred from the vertical distributions of its $\delta^{15} \mathrm{~N}, \delta^{13} \mathrm{C}$ and $\delta^{14} \mathrm{C}$. Deep-Sea Res I 44:1957-1979

Nakatsuka T, Masuzawa T, Kanda J, Kitazato H, Shirayama Y, Shimanaga M, Yamaoka A (2003) Particle dynamics in the deep water column of Sagami Bay, Japan. I: origins of apparent flux of sinking particles. Prog Oceanogr 57: 31-45

Nomaki H, Heinz P, Hemleben Ch, Kitazato H (2005a) Behavior and response of deep-sea benthic foraminifera to freshly supplied organic matter: a laboratory feeding experiment in microcosm environments. J Foram Res 35: 103-113

Nomaki H, Heinz P, Nakatsuka T, Shimanaga M, Kitazato H (2005b) Species-specific ingestion of organic carbon by deep-sea benthic foraminifera and meiobenthos: in situ tracer experiments. Limnol Oceanogr 50:134-146

Nomaki H, Heinz P, Nakatsuka T, Shimanaga M and others

Editorial responsibility: Otto Kinne,

Oldendorf/Luhe, Germany
(2006) Different ingestion patterns of ${ }^{13} \mathrm{C}$-labeled bacteria and algae by deep-sea benthic foraminifera. Mar Ecol Prog Ser 310:95-108

Post DM (2002) Using stable isotopes to estimate trophic position: models, methods and assumptions. Ecology 83: 703-718

Shimanaga M, Shirayama Y (2000) Response of benthic organisms to seasonal change of organic matter deposition in the bathyal Sagami Bay, central Japan. Oceanol Acta 23:91-107

Shimanaga M, Kitazato H, Shirayama Y (2000) Seasonal patterns of vertical distribution between meiofaunal groups in relation to phytodetritus deposition in the bathyal Sagami Bay, central Japan. J Oceanogr 56:379-387

Shimanaga M, Kitazato H, Shirayama Y (2004) Temporal patterns in diversity and species composition of deep-sea benthic copepods in bathyal Sagami Bay, central Japan. Mar Biol 144:1097-1110

Smith CR, Hoover DJ, Doan SE, Pope RH, DeMaster DJ, Dobbs FC, Altabet MA (1996) Phytodetritus at the abyssal seafloor across $10^{\circ}$ of latitude in the central equatorial Pacific. Deep-Sea Res II 43:1309-1338

Soltwedel T (2000) Metazoan meiobenthos along continental margins: a review. Prog Oceanogr 46:59-84

Suhr SB, Pond DW, Gooday AJ, Smith CR (2003) Selective feeding by benthic foraminifera on phytodetritus on the western Antarctic Peninsula shelf: evidence from fatty acid biomarker analysis. Mar Ecol Prog Ser 262:153-162

Sullivan MJ, Moncreiff CA (1990) Edaphic algae are an important component of salt marsh food webs: evidence from multiple stable isotope analyses. Mar Ecol Prog Ser 62:149-159

Vander Zanden MJ, Rasmussen JB (2001) Variation in $\delta^{15} \mathrm{~N}$ and $\delta^{13} \mathrm{C}$ trophic fractionation: implications for aquatic food web studies. Limnol Oceanogr 46:2061-2066

> Ward JN, Pond DW, Murray JW (2003) Feeding of benthic foraminifera on diatoms and sewage-derived organic matter: an experimental application of lipid biomarker techniques. Mar Environ Res 56:515-530

Yokoyama H, Tamaki A, Koyama K, Ishihi Y, Shimoda K, Harada K (2005) Isotopic evidence for phytoplankton as a major food source for macrobenthos on an intertidal sandflat in Ariake Sound, Japan. Mar Ecol Prog Ser 304: 101-116

Yoshii K, Melnik NG, Timoshkin OA, Bondarenko NA, Anoshko PN, Yoshioka T, Wada E (1999) Stable isotope analyses of the pelagic food web in Lake Baikal. Limnol Oceanogr 44:502-511

Yoshioka T, Wada E, Hayashi H (1994) A stable isotope study on seasonal food web dynamics in a eutrophic lake. Ecology 75:835-846

Submitted: July 20, 2007; Accepted: October 29, 2007

Proofs received from author(s): March 17, 2008 